\title{
Hrvatsko narodno vijeće od 1974. do 1990.
}

\author{
Tanja Trošelj Miočević *
}

\begin{abstract}
Sažetak
U ovom radu prikazuje se povijest nastanka i rada Hrvatskoga narodnoga vijeća u redovima hrvatske političke emigracije. Poseban naglasak stavljen je na povijest hrvatske političke emigracije poslije završetka Drugoga svjetskoga rata, nastanak različitih političkih pokreta $i$ organizacija, kao $i$ njihove međustranačke odnose. Rad također tematizira političke događaje 70-ih godina prošloga stoljeća u Domovini, kada je državno vodstvo u Jugoslaviji s Titom na čelu smijenilo vodstvo Centralnoga komiteta saveza komunista republike Hrvatske. Među najpoznatijim sudionicima kulturno-političkoga pokreta, kako su još zvali Hrvatsko proljeće, bili su Savka Dabčević Kučar, Miko Tripalo, a među studentima Dražen Budiša i Ivan Zvonimir Čičak. Oni, kao i brojni drugi, osuđeni su na zatvorske kazne, a staroj hrvatskoj instituciji Matici hrvatskoj bio je zabranjen rad. Također se u radu opisuju reakcije hrvatske političke emigracije na nastale političke promjene u Hrvatskoj.
\end{abstract}

Ključne riječi: Hrvatsko narodno vijeće; emigracija; iseljeništvo; politička emigracija; političke stranke; iseljena Hrvatska.

\section{Uvod}

Nakon sloma i propasti Nezavisne Države Hrvatske (NDH), u svibnju 1945. godine, stotine tisuća vojnika, pripadnika oružanih snaga te države, zajedno s civilima, povlačili su se prema austrijsko-jugoslavenskoj granici ispred jugoslavenskih komunista i partizanskih jedinica pod tadašnjim vodstvom Josipa Broza Tita, budućega predsjednika druge Jugoslavije (Geiger, 2003, 189-216).

Naivno vjerujući Britancima kako će prihvatiti predaju Hrvatskih oružanih snaga i da će im zapadne savezničke vojne snage, stacionirane na austrijsko-jugoslavenskoj granici, odnosno njihove države, pomoći u borbi protiv komunista, vojnici su predali svoje oružje na zahtjev britanskih zapovjednika (Prcela i Živić, 2001, 12). Opće je poznata njihova sudbina. Mnogi vojnici i civili izručeni su Tito-

* Tanja Trošelj Miočević, doktorandica, Hrvatski studiji Sveučilišta u Zagrebu. Adresa: Borongajska cesta 83d, 10000 Zagreb, Hrvatska. ORCID iD: https://orcid.org/0000-0001-6434-5823. E-adresa:tanja.troselj@gmail.com 
vim partizanima, koji su ih u vagonima vratili u Jugoslaviju. Oni koji nisu tragično završili na bleiburškom polju, a izbjegli su izručenje Jugoslaviji, odvedeni su u izbjegličke logore, uglavnom u Italiji i Austriji (Tolstoy, 1986, 131-137; Sopta, 1982, 26-27).

Bleiburška tragedija ostavila je velike posljedice i traume među Hrvatima širom svijeta. Trebalo je proći nekoliko desetljeća da se zaliječe rane te velike hrvatske tragedije, ako su uopće i do danas zaliječene. Jednako tako, tek nakon nekoliko godina pripadnici i simpatizeri NDH uspjeli su se organizirati i počeli osnivati političke stranke širom svijeta (Sopta, 2004a).

Hrvati u iseljeništvu koji nisu prihvaćali Jugoslaviju kao svoju državu, a politički su bili angažirani i djelovali u različitim političkim strankama, vjerovali su, bolje reći maštali, kako će doći do sukoba između dva ideološki podijeljena bloka, jednoga demokratskoga u zapadnom svijetu, na čijem su se čelu nalazile Sjedinjene Američke Države (SAD) i drugoga komunističkoga, na čelu sa Savezom Sovjetskih Socijalističkih Republika (SSSR), te da će Hrvati uspjeti obnoviti svoju državu. ${ }^{1}$ U hrvatskim iseljeničkim zajednicama širom svijeta djelovale su i neke utjecajne političke stranke, kao što je Hrvatska seljačka stranka (HSS) i Hrvatski oslobodilački pokret (HOP), čija je glavna ideja bila potreba za hrvatskim jedinstvom i zajedničkim djelovanjem protiv neprijatelja zvanoga komunistička Jugoslavija.

\section{Hrvatska seljačka stranka i Hrvatski oslobodilački pokret}

Obnavljanje hrvatske države bila je politička iluzija i nemoguća misija. Naime, dvije vodeće i najutjecajnije političke stranke, HSS i HOP, obje s mnogobrojnim članstvom i simpatizerima u hrvatskoj emigraciji, zastupale su stav da svaka od njih ima isključivo pravo govoriti i predstavljati hrvatski narod u slobodnom zapadnoeuropskom svijetu. Vodstvo HSS-a taj je svoj stav temeljilo na rezultatima posljednjih demokratski održanih izbora u Jugoslaviji prije Drugoga svjetskoga rata, a vodstvo HOP-a temeljilo je svoj stav na tome da su oni nasljednici vlasti NDH (Korsky, 1991, 215-228; Jareb, 1995, 125; Čizmić, 2004b; Sopta, 2004b; Čizmić i dr., 2005).

1 Ante Pavelić, u dopisu od 1. rujna 1957. godine, pisanom na memorandumu Poglavnik Nezavisne države Hrvatske, dao je osvrt na događaje u međunarodnoj politici te ga je poslao na sve podružnice HOP-a širom svijeta: »Međutim nalozi Moskve su morali biti izvršeni, i Beograd je bio zaigrao ulogu odpadnika, koje je zavaravanje bilo potrebno Moskvi, a usput i koristilo Jugoslaviji, sve dok nisu nastupili momenti, kada Moskva to više nije smatrala potrebnim, a za što je opravdanje prema vani dala okolnost promjene osobe na čelu moskovske vlade, a koje su osobe ujedno i na čelu sovjetskog komunizma. Uslied toga su došli posjeti iz Moskve Beogradu, i posjet Tita Moskvi, kojom je prilikom dobio Tito u dužnost i druge nove zadaće. Napose sada nakon sastanka Tita - Hruščova u Bukureštu, izgleda, da se sada ne nastoji igrati odpadničtva, jer se je Moskva počela služiti novim taktikama u svome pripremanju za osvajanje vlasti u svim državama u sviietu, i tu činjenicu sada treba imati pred očima, jer će sada konačno u zapadnjačkom svijetu i oni, koji su tobožnji Titoizam polagali neku važnost, morati uviditi, da to nije bila nikakva realnost « (Memorandum Poglavnik Nezavisne Države Hrvatske: Osvrt na događaje u međunarodnoj politici, dr Ante Pavelić, 01. rujna 1957.) 
Antagonizam između vodstava i članova tih dviju političkih stranaka, koji je jasno dolazio do izražaja u njihovim službenim novinama, nanio je goleme štete i pridonio razdoru i neslozi u hrvatskim zajednicama širom svijeta. ${ }^{2}$

Politička kriza i obezglavljeno vodstvo HSS-a poslije završetka Drugoga svjetskoga rata te pomanjkanje dijaloga, dodira i koordinacije rada između vodstva stranke i njezina članstva na terenu izazvali su veliku krizu u redovima HSS-a, od koje se ona nije nikada uspjela oporaviti (Sopta, 2004b; 2004c; 2004d). Zbog političke neaktivnosti Ante Pavelića i njegovih sljedbenika i simpatizera u Buenos Airesu i šire, nekadašnji istaknuti dužnosnici u NDH Ivan Oršanić i Ivo Korsky osnovali su Hrvatsku republikansku stranku 1951. godine u Buenos Airesu (Korsky, 1991, 226). S druge strane, relativno brzo nakon osnivanja HOP-a 1956. godine u Buenos Airesu, na čelu s Antom Pavelićem, došlo je do velikih političkih okršaja unutar pokreta, koji je uzrokovao osnivanje velikoga broja drugih stranaka.

U redovima HOP-a došlo je do sukoba, te su disidenti osnovali stranku HOP Reorganizacija (HOP-R), na čelu s bivšim ministrom u vladi NDH Vjekoslavom Vrančićem (Sopta, 2012, 245; Krolo, 2009, 186). S Antom Pavelićem i vodstvom HOP-a razišao se je i Vinko Nikolić, koji je pokrenuo časopis Hrvatska revija, tromjesečnik s kojim se je preselio u Španjolsku. Rascjep u redovima HOP-a nije prestao, pa je u Caracasu (Venezuela) 1958. godine osnovan Hrvatski odbor za Venezuelu, koji je mnogo godina poslije imao važnu ulogu prilikom osnivanja HNV-a. U Buenos Airesu 1960. godine osnovan je Hrvatski narodni odpor, još jedna frakcijska grupa unutar HOP-a. Mnogo ranije, 1950. godine u Njemačkoj u Münchenu, osnovan je Hrvatski narodni odbor (Krolo, 2009, 85). Sve te novoosnovane političke organizacije imale su svoje novine. Hrvatski glas bio je službeno glasilo Hrvatske seljačke stranke, čije se uredništvo nalazilo u kanadskom gradu Winnipegu. Hrvatska država bilo je službeno glasilo Hrvatskoga narodnoga odbora, a izlazilo je u Münchenu. Glasila Hrvatska (Buenos Aires), Nezavisna država Hrvatska (Toronto) i Spremnost (Sydney) bila su samo neka od službenih glasila Hrvatskoga oslobodilačkoga pokreta, a tromjesečnik Republika Hrvatska

2 Iz teksta objavljenog 1966. godine u časopisu Republika Hrvatska, koji je izlazio u Buenos Airesu, u kojem Ivan Oršanić kritizira politiku Vladka Mačeka prema NDH: »Pišete da su Nijemci nudili N.D.H. na tanjuru, što ste odbili bez PROMIŠLJANJA, jer ste ZNALI daje to samo udica, i jer ste bili uvjereni da Hitler neće pobijediti [...] Vi se smatrate predsjednikom demokratske stranke, pa kako ste mogli i smjeli uzeti sebi za pravo, da čak i bez promišljanja i bez odlučivanja predstavnika stranke odbijete jedan prijedlog vrlo važnog medjunarodnog značenja? S kakvim ste to promišljanjem pristupili 'Trojnom paktu' na bazi Jugoslavije i u društvu sa Cvetkovićem, a odbili ste to isto, bez ikakvog promišljanja, na bazi Države Hrvatske i bez Cvetkovića? «(Oršanić, 1966, 9); Hrvatske novine Danica iz Chicaga 1. studenoga 1948. objavile su prilog Silvija Grubišića Mjesto osobnog pisma. Taj prilog prenijelo je 15. studenoga 1948. glasilo Hrvatska pod drugim naslovom Hrvatsku vašu i našu, može ponovo zadesiti kobni udes, da bude uklopljena u nekakvu 'Jugoslaviju'. Fra Grubišić polemizira s idejama Vladka Mačeka objavljenim u službenom glasilu Hrvatske seljačke stranke Hrvatski glas te piše: »Kakav se pozitivan rad na oslobođenje naroda i uzpostavu vlastite države može očekivati od one grupe, čije novine mogu napisati kao što je ova [...] da na teritoriju, koji predstavlja Hrvatsku, ne može postojati bilo kakva državna tvorevina, koja u sebi ne bi sadržavala sve elemente jedne Jugoslavije, znači biti ili politički ignorant ili ustaša « (Grubišić, 1948, 3). 
(Buenos Aires) i novine Hrvatska budućnost (Los Angeles) bili su službena glasila Hrvatske republikanske stranke. Odpor, a kasnije Otpor, kao i publikacije koje su tiskane u izdanju Drina pressa u Španjolskoj, bile su službena glasila Hrvatskoga narodnoga otpora, u kojima su iznosile svoje stavove i programe. Između mnogih članaka i često oštrih diskusija i optužbi jednih prema drugima, koje su uglavnom bile temeljene na "grijesima i propustima" iz prošlosti, može se primijetiti da urednici i vođe tih stranaka propagiraju ideju potrebe ujedinjenja državotvornih stranaka i jedinstvenoga nastupa u javnosti (Kušan, 2000, 137). Međutim, zbog osobnih "liderskih" ambicija pojedinih vođa pokreta i stranaka to se nije ostvarilo. Bilo je i drugih ozbiljnih razloga, poput stranačkoga suparništva, djelovanja agenata jugoslavenske tajne službe, poznate pod imenom UDBA, kao i agenata država u kojima su Hrvati živjeli i politički djelovali, tako da plan ujedinjenja različitih političkih organizacija i stranaka u jedinstvenu "hrvatsku frontu" nije bilo moguće realizirati. Zbog loših međuljudskih odnosa i neprijateljstva koje je vladalo između najjačih političkih organizacija i njihovih vođa, a koje se prenosilo među hrvatskim iseljenicima širom svijeta putem stranačkih glasila, pojavila se je malodušnost koja je uništavala aktivistički žar i elan na terenu. Zbog tih razloga članstvo u strankama počelo se osipati i paralelno s time velik broj Hrvata, inače neovisnih u svojem djelovanju, počeli su se udaljavati i distancirati od aktivnosti u hrvatskim zajednicama. Istodobno, u redovima hrvatske političke emigracije sve više i više propagirana je ideja o potrebi osnivanja jednoga zajedničkoga tijela koje bi predstavljalo i govorilo u ime Hrvata u cijelom svijetu. Iako nije došlo do ujedinjenja političkih stranaka u jedno opće tijelo koje bi predstavljalo sve Hrvate u slobodnom demokratskom svijetu, ideja i ostvarenje želje o hrvatskom političkom jedinstvu ipak je urodila plodom.

\section{Hrvatsko narodno vijeće}

Na šestom hrvatskom saboru u rujnu 1961. godine u Chicagu, prisutni delegati koji su predstavljali mnogobrojne političke organizacije i razna hrvatska društva, uspjeli su naći kompromisno rješenje i formirati odbor koji su nazvali Privremeno Hrvatsko narodno vijeće (Čizmić, 2004b).

Glavni zadatak toga vijeća bio je napraviti organizacijske pripreme i sazvati općehrvatsku konvenciju ili kongres, na kojem bi se raspravljalo o potrebi i mogućnosti stvaranja jednoga zajedničkoga hrvatskoga tijela u svijetu, koje bi bilo »nositelj općehrvatske oslobodilačke borbe u emigraciji (Izvršni odbor HNV, 1985, 26).

Članovi Privremenoga Hrvatskoga narodnoga vijeća uspjeli su u danim okolnostima i mukotrpnim radom, u vrlo kratkom vremenu, sazvati Svehrvatski kongres, koji je održan od 29. kolovoza do 2. rujna 1962. godine u New Yorku. Domaćin kongresa bila je organizacija Ujedinjeni Američki Hrvati, čije je vodstvo za tu prigodu uputilo poziv svim političkim strankama, pokretima, društvima, kao i istaknutim pojedincima u emigraciji. Kongresu se nisu odazvali predstavnici HOP-a i HSS-a. Razlog su njihovi dobro poznati stavovi da jedino oni, naravno 
pojedinačno, mogu govoriti i predstavljati Hrvate u svijetu. No bez obzira na nedolazak predstavnika tih dviju stranaka, u tom trenutku najvažnije i najutjecajnije političke stranke, koje su imale i najbrojnije članstvo, nakon nekoliko dana zasjedanja prihvatile su 31. kolovoza 1962. godine Načelnu deklaraciju i Privremeni pravilnik organizacije, kojoj su dali ime Hrvatsko narodno vijeće (HNV). Na kongresu izabrano je i vodstvo organizacije: predsjednik Ibrahim Džinić (SAD), dopredsjednik Miro Gal (SAD), tajnik Tomislav Mesić (SAD) te članovi Branimir Jelić (Njemačka), Ivan Oršanić (Argentina), Milivoj Mostovac (Kanada), Milivoj Blažeković (Argentina) i Srećko Rover (Australija) (Sopta, 2012, 297; Kušan, 2000, 135-141).

Jedan od glavnih zaključaka kongresa bio je da se u roku od dvije godine ponovno sazove zasjedanje, na kojem bi se nastavila razvijati strategija i daljnje planiranje političkoga djelovanja u svijetu, ali i prema Domovini (Čizmić i dr., 2005, 423). Nažalost, zbog velikih nesuglasica političke naravi, kao i već spomenutoga osobnoga neprijateljstva između pojedinih vođa stranaka, drugi saziv toga kongresa nikad se nije dogodio. Jedan od glavnih razloga bio je u činjenici da su se Branko Jelić i Ivan Oršanić nastojali nametnuti »kao jedini koji mogu odlučivati u osnovanom Hrvatskom narodnom vijeću « (Kušan, 2000, 135). Taj neuspjeh organizacije drugoga kongresa imao je negativne učinke u redovima hrvatske političke emigracije, tako da su mnogi istaknuti emigrantski političari i neovisni pojedinci izgubili svaku nadu da se taj projekt može ostvariti, bar ne u bližoj budućnosti (Kušan, 2000, 136). Međutim, događaji koji su se zbivali poslije 1966. godine na političkoj sceni u emigraciji, kao i u Domovini, dali su novu snagu i poticaj da se ponovno pokuša ostvariti i formirati jedno zajedničko tijelo. Među važne događaje treba spomenuti da je u HOP-u došlo do velikoga raskola. Dio je stranačkoga vodstva, na čelu s Vjekoslavom Vrančićem, i velik broj članova, nezadovoljnih dotadašnjom politikom vođenja organizacije, napustio HOP, te su 5. siječnja 1966. godine u Buenos Airesu osnovali novu stranku pod nazivom HOP-Reorganizacija. Tada su prisutni sudionici izabrali Privremeni radni odbor za reorganizaciju HOP-a. Vijest o rascjepu odjeknula je među političkim aktivistima širom svijeta, a osobito među članovima HOP-a. Mnogi članovi napustili su organizaciju i priključili se novonastaloj organizaciji na čelu s izabranim predsjednikom Vjekoslavom Vrančićem (Čizmić i dr., 2005, 374).

\section{Kontinentalna vijeća}

HOP-Reorganizacija (HOP-R) zalagala se za veći stupanj demokracije u vođenju stranke, kao i za veću suradnju s drugim hrvatskim državotvornim strankama širom svijeta. Odmah nakon osnivačke sjednice vodstvo stranke založilo se za ideju stvaranja jednoga zajedničkoga hrvatskoga središnjega tijela, prvo u Argentini, a zatim u cijeloj Južnoj Americi (Krolo, 2009, 181).

Nekoliko godina nakon osnivanja, 1968. godine dolazi do sastanka između predstavnika HOP-R iz Argentine i Ujedinjenih Američkih Hrvata, na kojem je, između ostalih zaključaka, usvojena jedna važna odluka. Naime, na sastanku 
je zaključeno da se pristupi osnivanju kontinentalnih vijeća za uspostavu Države Hrvatske s ciljem što bržega i što lakšega stvaranja središnje organizacije (Krolo, 2009, 231). Ubrzo nakon toga sklopljenoga dogovora, 29. lipnja 1969. godine u Clevelandu dvadeset sjevernoameričkih i kanadskih organizacija osnovale su Sjevernoameričko vijeće za nezavisnost Hrvatske (Čizmić i dr., 2005, 406).

Nekoliko mjeseci poslije, 6. ožujka 1970. godine u Buenos Airesu, predstavnici Hrvatskoga narodnoga odpora, Hrvatske republikanske stranke, Hrvatskoga domobrana i HOP-R uspjeli su postići dogovor te su formirali Vijeće Hrvata Južne Amerike za uspostavu države Hrvatske (Izvršni odbor HNV, 1985, 27).

\section{Politički događaji potkraj 60-tih i početkom 70-tih godina}

Pokušaj da se i u Europi stvori kontinentalno vijeće s predstavnicima Hrvatskog narodnoga odbora, Ujedinjenih Hrvata Njemačke i Hrvatske republikanske stranke doživio je neuspjeh jer se nije uspio postići dogovor s američkim kontinentalnim vijećima »o vrsti i zadatku središnjeg hrvatskog predstavništva « (Izvršni odbor HNV, 1985, 27).

Paralelno s tim političkim gibanjima u emigraciji s jedne strane i novim događanjima na političko-kulturno-gospodarskoj sceni u domovini s druge strane, kada je državni vrh u Jugoslaviji sa Titom na čelu smijenio vodstvo Centralnoga komiteta saveza republike Hrvatske i osudio ih na zatvorske kazne, kao i mnoge kulturne radnike, intelektualce, studente. Svi ti događaji u domovini pokazali su i dokazali da je hrvatska politička emigracija bila nespremna i nije znala kako reagirati.

U kratkom vremenskom razdoblju u Jugoslaviji 1966. godine smijenjen je Aleksandar Ranković, najmoćniji političar u državi uz Tita, a u Hrvatskoj je 1967. godine objavljena Deklaracija o nazivu i položaju hrvatskoga književnoga jezika.

Potkraj šezdesetih godina i početkom sedamdesetih iz Jugoslavije je otišlo na privremeni rad u inozemstvo gotovo pola milijuna građana. Njih 250.000 tisuća bilo je iz Hrvatske, 130.000 tisuća iz Bosne i Hercegovine, a skoro 100.000 iz Srbije. No točnije je reći da je Jugoslaviju napustilo gotovo 700.000 tisuća građana, kada se radno sposobnomu stanovništvu pribroje i članovi obitelji koji su zajedno s njima emigrirali (Krolo, 2009, 55-60).

Hrvatska politička emigracija, bolje rečeno njezini politički najutjecajniji pojedinci koje su činili lideri pokreta i stranaka, glavni urednici stranačkih glasila, urednici neovisnih novina poput Jakše Kušana i njegovih novina Nova Hrvatska, Vinka Nikolića, nakladnika Hrvatske revije, neovisni hrvatski intelektualci poput Bogdana Radice, Stanka Vujice, Ante Kadića, Jure Prpića, Mate Meštrovića i ostalih, našli su se tako pred novim izazovom, na koji se nije znalo odgovoriti, niti kako tretirati građane iz Jugoslavije na privremenom radu u inozemstvu, od kojih su većina bili Hrvati (Čizmić, 1996, 431-436). Pad i slom Hrvatskoga proljeća, na čelu sa Savkom Dabčević Kučar, Mikom Tripalom, Perom Pirkerom i Markom Koprtalom, te zatvaranje studentskih vođa Dražena Budiše, Zvonimira Čička, Ante Paradžika i hrvatskih intelektualaca kao što su bili Franjo Tuđman, 
Marko Veselica, Vlado Gotovac i drugi, izazvao je burne reakcije Hrvata širom svijeta. U znak podrške i solidarnosti sa smijenjenim vodstvom komunističke partije Hrvatske, zatvorenim sveučilišnim profesorima, piscima, intelektualcima i vođama studentskoga pokreta, u svim hrvatskim zajednicama širom svijeta organizirani su javni prosvjedi na glavnim gradskim trgovima, ispred zgrada jugoslavenskih diplomatskih predstavništava. Nije bilo hrvatske zajednice u svijetu gdje nisu organizirani javni prosvjedi i poslane peticije državnim institucijama (Sopta, 2012, 336-337).

Bitno je istaknuti da je u tim javnim nastupima došlo do zajedničkoga i dobro organiziranoga djelovanja svih političkih stranaka i pokreta, različitih kulturnih i drugih društava. Potaknuti novonastalom političkom situacijom i događajima u redovima hrvatske političke emigracije, ali i u Domovini, reakcija je bila takva da su se nakon neuspjelih pokušaja političkoga povezivanja i ujedinjavanja ponovno pokrenuli utjecajni politički lideri u emigraciji, poput Vjekoslava Vrančića, Janka Skrbina, Dinka Šljaka, Stanka Vujice, Častimira Majića, Ivana Jelića, Ive Korskoga, Kazimira Katalinića, Mire Gala, Mile Markića, Kerima Reisa i ostalih, te su ohrabreno krenuli prema formiranju HNV-a. Hrvatski emigrantski tisak bez izuzetaka prenosio je vijesti iz Domovine uz popratni komentar svojih urednika i suradnika, kao i reakcije Hrvata širom svijeta na novonastale događaje. Može se reći da su emigrantska glasila sa svojim sadržajima iz domovine preko noći postala zanimljiva svima. Kroz njih se je razvila otvorena diskusija, iznosili različiti prijedlozi o hitnoj potrebi ujedinjenja svih državotvornih stranaka u jednu jaku jedinstvenu frontu (Čizmić, 2004b; Čizmić i dr., 2005, 405-422; Sopta, 2012, 299). Novonastali i otvoren dijalog pridonio je tomu da se je 1974. godine, točnije od 1. do 3. veljače 1974. godine, u Torontu održao osnivački sabor HNV-a. No prije sazivanja toga sabora važno je spomenuti neke događaje koji su prethodili njegovu sazivanju.

\section{Prethodnice sabora u Torontu}

Prvo, u travnju 1973. godine Hrvatski odbor za Venezuelu objavio je Poziv svim Hrvatima izvan domovine (Izvršni odbor HNV, 1985, 27). Taj poziv čija je glavna poruka bila da se osnuje Hrvatsko narodno predstavništvo, bio je objavljen u svim emigrantskim glasilima, kao i na hrvatskim radijskim programima. Ideja je pozdravljena i naišla je na podršku u golemoj većini hrvatskih zajednica širom svijeta (Izvršni odbor HNV, 1985, 26). Za razliku od neuspjela pokušaja stvaranja HNV-a iz 1962. godine u New Yorku, taj put predlagači iz Venezuele, između ostaloga, u svojem su nacrtu predložili osnivanje "mjesnih fondova" u svim hrvatskim zajednicama u svijetu. Na taj bi se način stvorila široka baza članova i simpatizera koji bi plaćanjem članarine i dobrovoljnim materijalnim prilozima omogućili i olakšali efikasnije djelovanje HNV-a.

Drugo, ideja o osnivanju fondova spremno je prihvaćena, osobito u SAD-u, gdje su se tijekom 1973. godine formirali Ujedinjeni hrvatski fondovi, kojima su se priključila mnogobrojna hrvatska društva u Clevelandu, Los Angelesu, Chica- 
gu i kanadskom gradu Vancouveru. Jedan od ciljeva, ako ne i glavni cilj novoosnovanih fondova, bilo je skupljanje što više materijalnih sredstava za potrebe političkoga djelovanja buduće organizacije (Čizmić, 2004a).

Treće, predstavnici Kontinentalnoga vijeća Južne Amerike i Hrvatskoga narodnoga odbora za Europu potpisali su 14. srpnja 1973. godine izjavu »kojom se zagovara stvaranje kontinentalnih vijeća u Europi i Australiji (Izvršni odbor HNV, 1985, 28). U potpisanom dokumentu osobito se ističe prijedlog o stvaranju jednoga središnjega hrvatskoga predstavništva. Zahvaljujući tomu sporazumu, 25. kolovoza 1973. godine ostvaren je sastanak u Münchenu, na kojem su predstavnici Hrvatskoga narodnoga odbora, Ujedinjenih Hrvata Njemačke, Hrvatske republikanske stranke i Radničkoga saveza iz Švedske jednoglasno usvojili prijedlog o osnivanju Europskoga kontinentalnoga vijeća, koji je osnovan tri mjeseca poslije, 4. studenoga 1973. godine, u mjestu Karlsrühe (Čizmić i dr., 2005, 424).

Četvrto, predstavnici Hrvatskoga narodnoga otpora, Hrvatske mladeži, Hrvatskoga narodnoga odbora, Ujedinjenih Hrvata i hrvatskih društava Bosna i Sydney potpisali su zajedničku izjavu 7. listopada 1973. godine o osnivanju Kontinentalnoga vijeća za Australiju (Čizmić i dr., 2005, 424).

Peto, u Chicagu se je od 23. do 25. studenoga 1973. godine održavao hrvatski sabor u zajedničkoj organizaciji Ujedinjenih američkih Hrvata i Ujedinjenih hrvatskih fondova.

Zbog atmosfere koja je zavladala u redovima hrvatske političke emigracije, kao i na samom zasjedanju hrvatskoga sabora, prisutni delegati donijeli su povijesnu odluku i najavili da će se od 1. do 3. veljače 1974. godine u Torontu održati osnivački sabor HNV-a. Tako je i bilo. U hotelu Andora u Torontu, tih je dana održan osnivački sabor HNV-a (Krolo, 2009, 232). ${ }^{3}$

\section{Osnivački sabor Hrvatskoga narodnoga vijeća}

Saboru su nazočili prisutni predstavnici svih političkih stranaka, osim HOP-a i HSS-a, što se moglo i očekivati s obzirom na njihova politička stajališta prema pitanju formiranja jednoga zajedničkoga predstavničkoga tijela. Međutim, saboru su se odazvali i sudjelovali u radu sjednice sabora istaknuti član HSS-a Dinko Šuljak, i Stanko Vujica, koji nije bio član ni jedne političke stranke. U trodnevnom zasjedanju sabora, između ostaloga, donesena je i usvojena osnivačka povelja, u kojoj piše da je glavni zadatak HNV-a »djelatno pomagati hrvatski narod svim prikladnim sredstvima u oslobođenju države Hrvatske (Čizmić i dr., 2005, 426).

3 Između ostalih zaključaka interesantno je spomenuti neke: 1. Umjesto imena Odbor za oslobođenje Hrvatske (ime političkoga tijela koje je sazvalo skup u Torontu), prisutni delegati i predstavnici političkih organizacija i društava Južne i Sjeverne Amerike, Europe i Australije prihvatili su ime Hrvatsko narodno vijeće; 2. Temeljni je zadatak OZOH-a djelatno pomagati hrvatski narod svim prikladnim sredstvima u oslobođenju hrvatske države (Hrvatsko narodno vijeće, 1975a). 
Na saboru je donesen i usvojen ustav HNV-a, u kojem između ostaloga stoji da je HNV stvoreno kao izvanstranačko tijelo. ${ }^{4}$ Za vrijeme zasjedanja Sabora izabrani su sljedeći dužnosnici: predsjednik Ante Došen (New York); dopredsjednici Vjekoslav Vrančić (HOP-R, Buenos Aires), Ivan Jelić (Hrvatski narodni odbor, Berlin), Ivo Korsky (Hrvatska republikanska stranka, Buenos Aires) i Dinko Šakić (Hrvatski narodni odpor, Valencija); glavni tajnik Božidar Abjanić (Cleveland); pomoćni tajnik Steve Skertić (Cleveland); glavni rizničar Ivo Kisić (Caracas); pomoćni rizničar Vlado Glavaš (Chicago); odbornici Ragib Avdić (Sydney), Janko Skrbin (Cleveland) i Drago Geoheli (Vancouver); nadzornici riznice Miro Gal (New York) i Stipe Čurić (Hamilton); predsjednik Časnoga suda Stanko Vujica (Wilkes Barre); članovi Časnog suda Gašpar Malvić (Caracas) i Taib Čordić (Toronto) (Izvršni odbor HNV, 1985, 31).

Osnivači HNV-a bili su svjesni činjenice da sabor kao vrhovno tijelo mora i može djelovati samo do onoga trenutka kada se na demokratskim izborima u neovisnoj i demokratskoj Hrvatskoj formira hrvatski državni sabor. Između ostalih poruka HNV-a treba izdvojiti onu koja glasi: »Ovim se činom proglašuje jedinstvo domovinske i iseljene Hrvatske, a ovim nadnevkom članice potpisnice Povelje o osnutku Hrvatskog Narodnog Vijeća, kao i one državotvorne organizacije, koje će se u ovoj zajedničkoj nam borbi još pridružiti, stavljaju se u službu hrvatskog naroda u domovini, i to kao predstavnici i tumači njegove volje i njegovih zahtjeva« (Izvršni odbor HNV, 1985, 32).

Iz toga se može zaključiti da se novoizabrani članovi sabora HNV-a nisu zanosili ni maštali o ideji da iseljena Hrvatska, ili pak oni sami, mogu zamijeniti narod u Domovini i preuzeti njegovu ulogu. Naprotiv, sebi su stavili u zadatak da političkim djelovanjem kroz HNV upoznaju svjetsku javnost s neravnopravnim položajem Hrvata u Jugoslaviji, kršenjem ljudskih prava, prava na slobodu riječi i mišljenja te iznad svega pravom hrvatskoga naroda na vlastitu slobodu (Hrvatsko narodno vijeće, 1975b; 1980; Amnesty International, 1985).

Vijest o održavanju prvoga sabora HNV-a u Torontu izazvala je velike reakcije u redovima hrvatske političke emigracije. U službenim glasilima HSS-a i HOP-a oštro je kritizirano osnivanje, negirajući $\mathrm{HNV}-\mathrm{u}$ pravo da govori u ime hrvatskoga naroda u slobodnom demokratskom svijetu. Pišući po njihovim ocjenama o velikom neuspjehu prvoga sabora HNV-a u Torontu, predsjednik HOP-a Srećko Pšeničnik, u službenom glasilu HOP-a Nezavisna Država Hrvat$s k a$, piše kako općenito hrvatska emigracija u Sjevernoj i Južnoj Americi, Europi

4 Zasjedanje Osnivačkog sabora Hrvatskog narodnog vijeća održanog od 1. do 3. veljače 1974. u prostorijama hotela Andora u Torontu, Kanada. Na Saboru su bili nazočni predstavnici svih političkih stranaka i društava osim HSS-a i HOP-a, zatim predstavnici Kontinentalnih vijeća, drugih društava i organizacija, i veći broj više ili manje istaknutih javnih radnika. Osnivačka povelja 1. Ime i zadatak: Hrvatsko Narodno vijeće (HNV) jest političko tijelo osnovano od hrvatskih organizacija, skupina i ustanova, koje stoje na načelu hrvatske državne samostalnosti i prava hrvatskog naroda da sam, nezavisno od vanjskih čimbenika, putem slobodno izabranog hrvatskog Sabora odlučuje o svojoj sudbini i organizira svoj život. Temeljni zadatak Hrvatskog Narodnog Vijeća jest djelatno pomagati hrvatski narod svim prikladnim sredstvima u oslobođenju države Hrvatske (Izvršni odbor HNV, 1985, 30-31). 
i Australiji, nije pokazala interes koji su organizatori održanoga sabora očekivali (Pšeničnik, 1974, 3).

Slično mišljenje poput Srećka Pšeničnika dijelio je i Marko Tarle, suradnik političkoga časopisa Na pragu sutrašnjice, koji je uređivao Ante Ciliga, u kojem je napisao: »Smatram da bi nakon neuspjeha Torontskog skupa i dubokog razočaranja nastalog u hrvatskoj emigraciji ( $\mathrm{tj}$. većem dijelu) uslijed toga pogrešnog poteza, bilo poželjno da se formira jedan odbor od istaknutih intelektualaca koji nisu politički kompromitirani, kao prvi iskorak za stvaranje jednog demokratskog fronta (Tarle, 1974, 90).

S druge strane, vijest o osnivanju HNV-a primljena je s velikim oduševljenjem u svim hrvatskim iseljeničkim zajednicama. Popularnost HNV-a rasla je iz dana u dan, tako da u jednom trenutku prema podatcima iz Biltena HNV-a »HNV sada ima 150 Mjesnih odbora, a do održavanja III. Sabora postoje izgledi da broj članova $\mathrm{HNV}$-a poraste na $12.000 \ll$.

Zbog boljega informiranja svojih članova i simpatizera, pokrenut je službeni Bilten HNV-a, u kojem se donose izvještaji o aktivnostima članova na terenu, kao i vijesti iz hrvatskih zajednica. Također se donose izvještaji o aktivnostima članova sabora na međunarodnom polju. Zbog golemoga posla vodstvo HNV-a došlo je do spoznaje da je za funkcioniranje i efikasan rad, posebno za suradnju i kontakte s članstvom na terenu, potrebno profesionalizirati ured, i zbog toga je uvedena dužnost glavnoga tajnika koji je radio svoj posao na profesionalnoj bazi. Biranje u sabor provodilo se je demokratskim putem tajnim glasovanjem za svoje favorite (Constitution of the Croatian National Congress, 1978; Glavno tajništvo, 1978).

Na prvom redovitom saboru HNV-a, održanom od 4. do 8. rujna 1975. godine u Torontu, došlo je do promjene na čelu toga središnjega tijela Hrvata u svijetu. Naime, taj put izabrani su: predsjednik sabora Dinko Šljak, predsjednik izvršnoga odbora Stanko Vujica, glavni tajnik Božidar Abjanić, pročelnik ureda za vanjske veze Bogdan Radica, pročelnik ureda za tisak i promidžbu Jakša Kušan, predsjednik nadzornoga odbora Častimir Majić i predsjednik časnoga suda Milan Blažeković (Izvršni odbor HNV, 1985, 38-39; Krolo, 2009, 232).

Svojom aktivnošću i raznim političkim akcijama HNV je unijelo jednu svježinu i novost u hrvatske zajednice širom svijeta te brzo preuzelo primat i vodeću ulogu koju su dotada imali HSS i HOP. Nakon iznenadne smrti Stanka Vujice 1976. godine za vrijeme svečane večere u gradu Londonu u provinciji Ontario u Kanadi, na njegov položaj izabran je Janko Skrbin, istaknuti politički emigrant iz Clevelanda. HNV dobilo je još veću političku važnost i ugled među hrvatskim emigrantima nakon što su bivši pripadnici Hrvatskoga proljeća, poput Brune Bušića, Franje Mikulića, Zlatka Markusa, Ivana Cerovca i još nekih, postali njegovi članovi. Vrlo brzo nakon pristupanja članstvu HNV-a, na drugom saboru HNV-a koji je održan 1977. godine u Bruxellesu, izabrani su na vodeće pozicije u Saboru. Franjo Mikulić izabran je za predsjednika, Bruno Bušić za pročelnika za promidžbu, a Zlatko Markus za pročelnika za vanjske veze (Sopta, 2012, 310).

Između ostalih zaključaka toga Sabora, hrvatskoj javnosti je poslana poruka HNV-a, u kojoj je posebno važno istaknuti da u hrvatskoj borbi ima mjesta za sve, i takozvane desničare ili pak ljevičare (Sopta, 2012, 311). 


\subsection{Minimalisti i maksimalisti}

Nažalost, kao i u drugim političkim organizacijama u hrvatskom iseljeništvu, tako i unutar HNV-a, od samoga njegova osnivanja pa do njegova prestanka djelovanja, neformalno su se stvorile dvije grupe sabornika koji su zastupali dijametralno suprotne političke stavove u vezi sa strategijom rada HNV-a. ${ }^{5}$ Jednu, nazvanu minimalistima ili konzervativcima, koja je činila većinu u Saboru, na čelu s Vjekoslavom Vrančićem, Častimirom Majićem, Jankom Skrbinom, Jakšom Kušanom, Hrvojem Lunom, poslije i Matom Meštrovićem i Mirkom Vidovićem, otvoreno i javno kritizirali su predstavnici druge skupine, takozvani maksimalisti ili proljećari zbog njihove oportunističke, smušene i iznad svega nejasne politike (Markus, 1978, 4-5; Mikulić, 1979, 9; Markus, 1982, 3-4; Kušan, 2000, 249-254, 254-258 i 259-262).

Neslužbeno, za lidera grupe maksimalista slovio je Bruno Bušić, ${ }^{6}$ koji je zajedno s Franjom Mikulićem, Zlatkom Markusom i Ivanom Cerovcem (Jurić, 1979, 24), nakon pada i sloma Hrvatskoga proljeća završio u emigraciji te je od svojih spomenutih političkih suparnika unutar HNV-a optuživan da propagira terorizam i prorusku orijentaciju. Uz spomenute proljećare, u maksimaliste su se, zbog zajedničkih političkih stavova i suradnje, svrstale dvije političke stranke - Hrvatska republikanska stranka i Hrvatski narodni otpor (Čizmić i dr., 2005, 428-429).

Prvi nesporazum između te dvije grupacije unutar HNV-a nastao je kada je Bruno Bušić, kao pročelnik za promidžbu, krenuo s izdavanjem Vjesnika, službenoga glasila HNV-a. U njemu je Bušić kao glavni urednik osim vijesti objavljivao i članke o aktualnim političkim i ekonomskim temama iz domovine. Nakon svega pet brojeva, Vjesnik je prestao izlaziti zbog pomanjkanja materijalnih sredstava. Iako je to bilo službeno glasilo HNV-a, glavni tajnik Hrvoje Lun odbio je platiti troškove tiskanja istoga. To je izazvalo veliko negodovanje i nezadovoljstvo među članovima na terenu. ${ }^{7}$

Ubojstvom Brune Bušića, 16. listopada 1978. godine (Uredništvo, 1979, 17), kojega je organizirala i provela UDBA, HNV je izgubio svojega »najdinamičnijeg dužnosnika i najbolju vezu s domovinskom opozicijom, a proljećari svog lidera, koji je tu skupinu držao homogenom i snažnom« (Čizmić i dr., 2005, 429).

5 Intervju s Alojzijom Buconjić, sabornicom HNV-a u iseljeništvu, povratnicom iz New Yorka, 25. ožujka 2018., u Zagrebu vodila autorica rada. Gospođa Buconjić bila je istaknuta politička aktivistica i članica vodstva Hrvatske republikanske stranke u New Yorku.

6 Bruno Bušić (Donji Vinjani kraj Imotskoga, 1939. - Pariz, 1978.), hrvatski političar i publicist, jedan je od najistaknutijih članova Hrvatskoga proljeća. Pisao je za mnoge revije i časopise te je bio jedan od urednika glasovitoga Hrvatskoga književnoga lista, a u iseljeništvu je vodio Ured za promidžbu HNV-a. Bušić je bio autor poznate Hrvatske deklaracije, kojom se htjelo upozoriti svjetsku javnost na nepravedan položaj Hrvata u Jugoslaviji. Kukavički, iz zasjede, ubio ga je agent Udbe 17. listopada 1978. godine. Pokopan je u Parizu, a ostatci su mu preneseni u Hrvatsku 16. listopada 1999. te pokopani u Aleji branitelja na zagrebačkom Mirogoju (Mijatović, 2010, 235-236 i 251); Bušić, Bruno. URL:http://www.enciklopedija.hr/natuknica.aspx?id=10351 (04.07.2019.).

7 Iz intervjua s emigrantom i povratnikom iz Chicaga Vladom Glavašem, u Zagrebu, 23. ožujka 2018. vodila autorica rada. 
Stalne konfrontacije i međusobna optuživanja unutar HNV-a rezultirala su velikim raskolom, što je na terenu dovelo do masovnoga napuštanja i odlaska članova. ${ }^{8}$ Nezadovoljni politikom koju su minimalisti vodili u ime HNV-a, Franjo Mikulić, Zlatko Markus i Stipe Bilandžić, koji su imali i glavne pozicije unutar sabora, demonstrativno su napustili HNV, u znak solidarnosti sa Zvonkom i Julienne Bušić, koji su legalno stekli pravo da budu kandidirani u sabor HNV-a, a to pravo im je osporeno. Njihov primjer slijedio je velik broj istomišljenika na terenu (Katalinić, 1979, 5; Sudar, 1979, 18-19).

Nastala polarizacija unutar HNV-a produbila se je i izlaskom Hrvatskoga narodnoga otpora iz HNV-a. U novonastaloj situaciji održan je 21. siječnja 1980. godine treći sabor HNV-a u Londonu, na kojem je za predsjednika izabran Mirko Vidović, pjesnik i bivši politički zatvorenik, koji je nakon izdržane zatvorske kazne u Jugoslaviji iselio u Francusku. Janko Skrbin zadržao je mjesto predsjednika izvršnoga odbora, a sveučilišni profesor Mate Meštrović izabran je za pročelnika za vanjske veze (Uredništvo, 1980).

Generacijske i ideološke razlike između pripadnika takozvanih "minimalista" i "maksimalista”, a iznad svega razlike u strategiji i taktici političkoga djelovanja prema Jugoslaviji, bile su glavni razlog zašto pripadnici te dvije skupine unutar HNV-a nisu više mogli ili pak htjeli nastaviti zajednički djelovati (Čizmić i dr., 2005, 428-429).

Već na četvrtom saboru HNV-a održanom 1982. godine u Torontu, a osobito na petom saboru održanom 1983. godine u Londonu, moglo se je uočiti da je HNV u velikoj krizi. Najbolji je primjer za to podatak da se za izbor u sabor prijavilo samo 47 kandidata, a primjerice za treći sabor bilo je prijavljeno 92 kandidata i isto toliki broj zamjenika (Sopta, 2012, 317).

\subsection{Hrvatski državotvorni pokret}

Nekoliko godina nakon svirepoga ubojstva Brune Bušića u Parizu, konstantnih prepirki i međusobnih optuživanja između pripadnika dva bloka unutar HNV-a, to jest između minimalista i maksimalista, bilo je očigledno da oni ne mogu nastaviti zajednički surađivati.

Nakon nekoliko godina, točnije 23.-25. siječnja 1981. godine u New Yorku, održan je seminar Hrvatskoga lista, na kojem je uz predstavnike Hrvatskoga narodnoga otpora sudjelovalo više od pedeset aktivista koji su za tu prigodu došli iz različitih gradova SAD-a, Kanade, Australije, Njemačke i Švedske (Uredništvo, 1981).

Nakon tri dana zasjedanja donesena je jednoglasna odluka o osnivanju Hrvatskoga državotvornoga pokreta. $\mathrm{Na}$ istom je zasjedanju izabran i privremeni izvršni odbor od pet članova: predsjednik Tomislav Kvaternik (alias Nikola Šte-

8 Ove su informacije prema Zapisniku sa sastanka hrvatskih aktivista USA i Kanade, organiziran 16. i 17. veljače, u prostorijama mjesnoga odbora HNV-a u Torontu. Na sastanku su sudjelovali delegati iz 25 gradova Sjever Amerike, većinom članovi HNV-a nezadovoljni politikom izvršnoga odbora HNV-a. 
dul), koji je tada živio u Škotskoj, potpredsjednik Ante Šuto (Australija), tajnik Marijan Gabelica (SAD), rizničar Marin Sopta (Kanada) i pročelnik za promidžbu Zlatko Markus (Švedska). Izabran je i nadzorni odbor: Drago Geoheli (Kanada), Josip Kuštra (SAD) i Franjo Vranković (Australija). Osnivanje Hrvatskoga državotvornoga pokreta nanijelo je velik udarac HNV-u, od kojega se ono nije nikada oporavilo. No i pored velikoga udarca koji je pretrpio, sabor HNV-a i dalje je nastavio sa svojim radom (Sopta, 2012, 322-323).

\subsection{Zasjedanje Sabora HNV-a u Zagrebu}

Šesti sabor HNV-a održan je 1986. u Londonu, a sedmi 1988. godine u španjolskom gradu Sitgesu, u blizini Barcelone.

Nakon uspostave demokratske i slobodne Republike Hrvatske predsjednik Franjo Tuđman poslao je službeni poziv sabornicima HNV-a, koji su tada održavali svoj izvanredni sabor 25.-27. kolovoza 1990. godine u Münchenu, da saborovanje nastave u Zagrebu, što su oni prihvatili (Čizmić, 2004c). Sabor HNV-a, koji je počeo u Münchenu, nastavio je svoj rad u hotelu Dubrovnik u centru Zagreba, a na kraju rada članovi sabora usvojili su sljedeću izjavu: »Hrvatsko narodno vijeće, državotvorno, izvanstranačko političko tijelo Hrvata u iseljeništvu, održalo je izvanredno zasjedanje svoga Sabora od 25. do 29. kolovoza u Münchenu i Zagrebu s ciljem da razmotri razvoj događaja u domovini, uzrokovan izbornom pobjedom Hrvatske demokratske zajednice i uspostavom zakonite hrvatske vlasti, te da donese potrebne zaključke o svom uključenju u novonastale demokratske procese u Hrvatskoj. [...] Zasjedanje Sabora HNV-a u Zagrebu simbolizira kraj jednog dugog, mukotrpnog razdoblja, u kojem se silom pokušalo spriječiti zajedništvo iseljene i domovinske Hrvatske. [...] Tijekom naših zasjedanja, došli smo do sljedećih zaključaka: iako su učinjeni važni koraci u afirmaciji hrvatske državotvornosti i pluralističke demokracije, naši neprijatelji rade protiv oživotvorenja prava hrvatskog naroda na samoodređenje do odcjepljenja. Rodoljubna dužnost nam nalaže potporu demokratski izabranoj vlasti pod predsjedništvom dr. Franje Tuđmana za očuvanje dosadašnjih i daljnjih dostignuća hrvatske državne suverenosti« (Čižmić i dr., 2005, 434).

Tim proglasom na zasjedanju sabora HNV-a u Zagrebu službeno je prestao njegov rad. Sabornici HNV-a, svaki za sebe, donijeli su odluku o svojem budućem političkom djelovanju. Većina njih učlanila se u Hrvatsku demokratsku zajednicu, neki su ostali neovisni, a neki su izabrali druge političke opcije. Tako je primjerice Mate Meštrović na listi Hrvatske narodne stranke izabran u Sabor Republike Hrvatske, a nakon prvoga mandata imenovan je veleposlanikom Republike Hrvatske u Bugarskoj. Pokušaj Jakše Kušana, bivšega urednika časopisa Nova Hrvatska iz Londona, da novine nastavi uređivati u Domovini, nakon kratkoga vremena završio je neuspjehom. Tomislav Bošnjak, član sabora HNV-a iz Australije, postao je generalnim konzulom Republike Hrvatske u Mississaugi u Kanadi, a Tomislav Domagoj Šola iz Kanade bio je imenovan generalnim konzulom u Clevelandu, poslije i u Chicagu (Čizmić i dr., 2005, 468). 


\section{Zaključak}

Politička grupacija nazvana Hrvatsko narodno vijeće osnovana je s ciljem da postane krovnom organizacijom koja će predstavljati Hrvate u cijelom svijetu, kao i Hrvate u Domovini koji ne mogu slobodno govoriti i propagirati ideju slobodne i demokratske Hrvatske. Vijest o osnivanju HNV-a 1974. godine u kanadskom gradu Torontu izazvala je veliko oduševljenje među Hrvatima na svim kontinentima. Osnivanje HNV-a, među ostalim, vratilo je kod mnogih političkih emigranata izgubljen optimizam i vjeru u ideju slobodne demokratske Hrvatske. No, HNV u Torontu nije nastao preko noći. Naprotiv, prvi pokušaj osnivanja sličnoga tijela završio je velikim neuspjehom nakon njegova osnivanja 1962. godine u New Yorku.

Odmah nakon osnivanja HNV-a ljudi su se masovno učlanjivali, osnivali mjesne odbore u svim hrvatskim zajednicama diljem svijeta. Na vrhuncu svoje moći HNV je imao više od deset tisuća članova u svijetu i više od stotinu mjesnih odbora. Sabor HNV-a, kao njegovo najviše političko tijelo, bio je sastavljen od trideset članova koji su birani na demokratski organiziranim izborima. Taj politički postupak biranja vodstva na demokratski način predstavljao je oživotvorenje demokracije za sve njegove članove. Iznad svega zbog njegova političkoga pluralizma, koji se je temeljio i zasnivao na ideološkim razlikama izabranih sabornika, koji su dolazili iz zemalja Južne Amerike, Australije, SAD-a, Kanade i Europe.

HNV je na najbolji način propagirao ideju slobodne i demokratske Republike Hrvatske u svijetu. Uspostavom i proglašenjem hrvatske neovisnosti, HNV je prestao postojati u znak potpore i priznavanja novoizabrane demokratske vlade Republike Hrvatske.

\section{Literatura}

Anon. Bušić, Bruno. U: Hrvatska enciklopedija. Leksikografski zavod Miroslav Krleža. URL: http://www.enciklopedija.hr/natuknica.aspx?id=10351 (04.07.2019.)

Amnesty International (1985). Yugoslavia Briefing: Political imprisonment in Yugoslavia. London: Amnesty International.

Čizmić, Ivan (1996). Emigration and Emigrants from Croatia between 1880 and 1980. GeoJournal, 38(4), 431-436.

Čizmić, Ivan (2004a). Danas više nema važnijeg hrvatskog političara koji bi se odricao hrvatske države ili se u tome sam kolebao. Vjesnik, 65, 1. rujna, 16.

Čizmić, Ivan (2004b). Oživjela ideja stvaranja sveopće hrvatske organizacije. Vjesnik, 65, 30. kolovoza, str. 21.

Čizmić, Ivan (2004c). Kraj mukotrpnoga razdoblja u kojem se silom pokušalo spriječiti zajedništvo iseljene i domovinske Hrvatske. Vjesnik, 65, 10. rujna, 15.

Čizmić, Ivan; Sopta, Marin; Šakić, Vlado (2005). Iseljena Hrvatska. Zagreb: Golden Marketing.

Geiger, Vladimir (2003). Osvrt na važniju literaturu o Bleiburgu 1945. Časopis za suvremenu povijest, 35(1), 189-216.

Glavno tajništvo (1978). Izbori za Sabor HNV-a su blizu. Vjesnik Hrvatskog narodnog vijeća, 3,4 . 
Grubišić, Silvije (1948). Hrvatsku vašu i našu, može ponovno zadesiti kobni udes, da bude uklopljena u nekakvu "Jugoslaviju". Hrvatska, Buenos Aires 15. studenoga, 3.

Hrvatsko narodno vijeće (1975a). Osnivačka povelja Hrvatskog narodnog vijeća. Vjesnik Hrvatskog narodnog vijeća $, 1,6$.

Hrvatsko narodno vijeće (1975b). Deklaracija prvog Sabora Hrvatskog narodnog vijeća. Vjesnik Hrvatskog narodnog vijeća, $1,7$.

Izvršni odbor HNV (1985). Priručnik za Mjesne odbore Hrvatskog narodnog vijeća 1974.1985. Caracas: Izvršni odbor HNV.

Jareb, Jere (1995). Pola stoljeća hrvatske politike 1895.-1945. Zagreb: Institut za suvremenu povijest.

Jurić, Jakov (1979). A onda dolazi 1971 - u emigraciji. Hrvatski list, 9-10, 24.

Katalinić, Kazimir (1979). Javna izjava Kazimira Katalinića, tajnika Sabora. Hrvatski list $12,5$.

Korsky, Ivo (1991). Hrvatski nacionalizam. Zagreb: Matica hrvatska.

Krolo, Tomislav (2009). Hrvatski politički emigrant 1941.-1991. Zagreb: vlastita naklada.

Kušan, Jakša (2000). U borbi za novu Hrvatsku. Rijeka: Otokar Keršovani.

Markus, Zlatko (1979). Šakal i lešinari. Hrvatski list, 3, 4-5.

Markus, Zlatko (1982). Hrvatska kao samostalna država koja bi imala palmeovski i brandtovski socijalizam. Hrvatski list, 4, 3 .

Mikulić, Franjo (1979). Tendencioznima i zlonamjernima dobronamjerno i načelno. $\mathrm{Hr}$ vatski list, 7, 9 .

Oršanić, Ivan (1966). Hrvatski revolucionarni proces. Republika Hrvatska, 68, listopad, 9.

Mijatović, Anđelko (2010). Bruno Bušić. Prilog istraživanju života i djelovanja (1939. 1978.). Zagreb: Śkolska knjiga.

Prcela, John Ivan; Živić, Dražen (ur.) (2001). Hrvatski holokaust: Dokumenti i svjedočanstva o poratnim pokoljima u Jugoslaviji. Zagreb: Društvo političkih zatvorenika.

Pšeničnik, Srećko (1974). Sastanak u Torontu. Nezavisna država Hrvatska, veljača-ožujak, 3.

Sopta, Marin (2004a). Borba za goli život, ogorčenost i mržnja prema komunistima. Vjesnik, 65 (7. i 8. listopad), 17.

Sopta, Marin (2004b). HSS i HOP neopravdano su svojatali legitimitet zastupanja i općehrvatskih i iseljeničkih interesa. Vjesnik, 65, 23. rujna, 18.

Sopta, Marin (2004c). Potpuna idejna i politička konfuzija i nesnalaženje. Vjesnik, 6522. rujna, 18.

Sopta, Marin (2004d). Šubašićev sporazum sa Titom izdaja hrvatskog naroda. Vjesnik, 65, 24. rujna, 18.

Sopta, Marin (1982). Razgovor sa gospodinom Danijelom Crljenom u glasilu Hrvatskog narodnog otpora. Otpor, 2, 26-27.

Sopta, Marin (2012). Hrvati u Kanadi: Oblikovanje hrvatske zajednice od 1945. do 1995. Zagreb: Institut društvenih znanosti Ivo Pilar.

Sudar, Drago (1979). Ustaše i proljećari. Hrvatski list, 9-10, 18-19.

Informativni Bilten Hrvatskog Narodnog Vijeća (1979). br. 2, New York, 19. listopada.

Tarle, Marko (1974). Anahronističke političke pojave u Hrvatskoj emigraciji. Na pragu sutrašnjice, urednik Ante Ciliga, 2-3, 90.

Tolstoy, Nikolai (1986). The Minister and the Massacres. London: Century Hutchinson.

Uredništvo (1979). Otkriven spomenik Bruni Bušću. Hrvatski list, 12, 17.

Uredništvo (1980). III Sabor Hrvatskog narodnog vijeća. Nova Hrvatska, 2, 10-11. 
Privremeni izvršni odbor Hrvatskog državotvornog pokreta (1981). Rezolucija o utemeljenju državotvornog pokreta. Hrvatski list, 2, 5.

Arhivsko gradivo

Constitution of the Croatian National Congress New York, 1978. Kopija originala u posjedu Tanje Trošelj Miočević

Intervju s Vladom Glavašem. 23. ožujak 2018. Zagreb. Snimak razgovora u posjedu Tanje Trošelj Miočević.

Intervju s Alojzijom Buconjić. 25. ožujak 2018. Zagreb. Snimak razgovora u posjedu Tanje Trošelj Miočević.

Memorandum Poglavnik Nezavisne Države Hrvatske: Osvrt na događaje u međunarodnoj politici, dr Ante Pavelić, 01. rujna 1957. Kopija originala u posjedu Marina Sopte.

Osnivačka povelja Hrvatskog narodnog vijeća. Toronto, 2. veljače, 1974. Kopija originala u posjedu Tanje Trošelj Miočević.

Violations of human and national rights of the Croatian people in Yugoslavia. Memodrandum submitted to the Madrid review conference on security and cooperation in europe by the Croatian National Congress, New York 1980. Kopija originala u posjedu Tanje Trošelj Miočević.

Zapisnik sa sastanka hrvatskih aktivista USA i Kanade (1979). održanog u gradu Torontu, 16. i 17. veljače u prostorijama Mjesnog odbora HNV-a -Toronto - 1621 Dipont Street. Kopija originala u posjedu Ivana Grbeše, Hamilton, Canada.

The Croatian National Council from 1974 to 1990

\section{Tanja Trošelj Miočević*}

\section{Summary}

At the end of WW II, Croatian emigrés found themselves to be divided and in the midst of organizational chaos due to political circumstances and the final outcome of the war. Three decades hence, an uncompromising battle raged between the two greatest and most influential political groups among Croatian emigrés. On one side, there was the Croatian Peasant Party (Hrvatska seljačka stranka or HSS), the oldest Croatian political party in the diaspora whose leaders and members upheld the politics of their founder, Stjepan Radić. On the other side was the Croatian Liberation Movement (Hrvatski oslobodilački pokret or HOP), founded by high-ranking officials and members of the armed forces of the failed Independent State of Croatia. Weary of confrontation among the various groups, Croatian emigrés addressed the necessity of developing a single powerful supra-party organization which, united and strong, would defend and promote the idea throughout the world that the Croatian people have a right to their own state. In 1971, the collapse of the Croatian Spring in the Homeland generated a tremendous reaction among Croats abroad and revived again the need for an organization which would unite all Croatian emigrés and take

* Tanja Trošelj Miočević, dipl. oec., Doctorand, Croatian Studies. University of Zagreb. Address: Borongajska cesta 83d, 10000 Zagreb, Croatia. E-mail: tanja.troselj@gmail.com 
action throughout the world to promote the idea of liberty and democracy for the Croatian people. In a short space of time, extensive preparations were made and thus the Croatian National Council (Hrvatsko narodno vijece or HNV) was established in 1974 at its inaugural meeting in Toronto. In the wake of democratic changes in Southeast Europe and in Yugoslavia, the leaders of the HNV gave their full backing to the new democratic parties founded in Croatia. Following the declaration of Croatian independence, the HNV ceased to exist, this being a sign of support and acknowledgement to the newly established democratic government of the Republic of Croatia.

Key words: Croatian National Council; emigration; emigrés; political parties; displaced Croatia. 